\title{
ALGAE GROWTH INHIBITION BY AQUEOUS EXTRACTS FROM ALTERNANTHERA PHILOXEROIDES AND UNDERLYING MECHANISMS
}

\author{
HUANG, Y. J. * HUANG, Y. - YAO, Y. T. - ZHOU, Z. Z. - ZHANG, J. - YANG, S. Y. - ZHOU, J. H. \\ - ZHOU, S. B.
}

School of Ecology and Environment, Anhui Normal University, Wuhu 241000, China

Collaborative Innovation Center of Recovery and Reconstruction of Degraded Ecosystem in Wanjiang Basin Co-founded by Anhui Province and Ministry of Education, Anhui Normal University, Wuhu 241000, China

Anhui Provincial Engineering Laboratory of Water and Soil Pollution Control and Remediation, Wuhu 241000, China

*Corresponding author

e-mail: yongjiehuang0108@163.com

(Received 28 ${ }^{\text {th }}$ Dec 2020; accepted $18^{\text {th }}$ Mar 2021)

\begin{abstract}
Using Microcystis aeruginosa as a research receptor, the inhibitory effects of 0.3-1.1 g/L root, stem and leaf extracts from Alternanthera philoxeroides on algae growth and their underlying mechanisms were studied. The biomass, oxygen radical $\left(\mathrm{O}_{2}^{-}\right)$, malondialdehyde (MDA), nucleic acid, microcystin and polysaccharide contents were determined and cell morphological and structural variations were observed. Results showed that the extracts from A. philoxeroides significantly inhibited the growth of M. aeruginosa in a concentration-dependent manner. In particular, root extract had the strongest inhibition effect, followed by stem and leaf extract. The growth of more than $80 \%$ of all M. aeruginosa was inhibited after $96 \mathrm{~h}$ exposure to $1.1 \mathrm{~g} / \mathrm{L}$ root extract. Besides, the damage degree of cells treated with root extract after $72 \mathrm{~h}$ was shown by the scanning electron microscope. With the accumulation of $\mathrm{O}_{2}^{-}$, the contents of all physiological indicators increased with higher extract concentrations, except for MDA content, which decreased first after $24 \mathrm{~h}$ culture at $0.3 \mathrm{~g} / \mathrm{L}$ treatment. In conclusion, A. philoxeroides had a certain ecological control capacity on M. aeruginosa growth by aggravating oxidative stress, destroying membrane permeability, changing cell structure and finally inducing plasmatorrhexis, but the specific action of allelochemicals it contained remained to be further explored.
\end{abstract}

Keywords: harmful algal blooms, allelopathy, growth inhibition, peroxidation reaction, microcystin, polysaccharide

\section{Introduction}

In recent years, intense agricultural production and living activities had led to a dramatic increase of $\mathrm{N}$ and $\mathrm{P}$ levels in water, which has caused severe eutrophication and frequent harmful algal blooms (HABs) (Lapointe et al., 2015). Among these, the most common is the occurrence of cyanobacteria cells over propagation whose dominant species include Microcysis, Oscillatoria, Anabaenopsis, Cylindrospermopsis etc. (Kaur et al., 2019). The end result not only seriously affects the biodiversity of aquatic ecosystem and the development of aquaculture, but also endangers human health (Carmichael and Boyer, 2015).

At present, the use of various techniques to restrain algal growth has been widely developed and applied. Physical and chemical processes mainly include filtration, ultrasonic treatment, ball clay flocculation and algaecide (copper sulfate and hydrogen peroxide), etc. (Greenfield et al., 2014; Han et al., 2019). Bioflocculation, algicidal 
bacteria, viruses, plant-derived compounds, fish and zooplankton are considered as costeffective, safe, ecologically healthy emerging biotechnologies for the control of algal blooms (Mecina et al., 2017; Pal et al., 2020), especially the effects of allelochemicals identified from plants on algae have attached much attention (Herrera et al., 2019).

Plants can release chemicals into the biological community to promote or inhibit the growth and development of themselves and other surrounding organisms directly or indirectly (Uddin et al., 2017). Allelopathic chemicals have been sought out in an array of plants, like Phragmitescommunis, Eichhornia crassipes and Pistia stratiotes Linn. Besides, allelochemicals are secondary metabolites of biosynthesis and are easily decomposed. According to their different properties and synthetic pathways, they can be divided into phenolic acids, terpenoids, alkaloids, etc. (Zhao et al., 2019). Results have shown that phenolic acids (Zhang et al., 2010), linoleic acids (Ni et al., 2015), flavonoids and tannins (Tazart et al., 2019) can strongly restrain the growth of $M$. aeruginosa, and may become promising alternatives to algae control.

$M$. aeruginosa is a typical cyanobacterium with a global distribution range. The large area coverage of $M$. aeruginosa in eutrophication freshwater ecosystems tends to cause lack of oxygen in water and inhibit photosynthesis of aquatic plants (Rzymski et al., 2020). What is more severe is that it can produce and release microcystins (monocyclic seven-peptide compounds synthesized from multifunctional protein complex) into the environment, and then gradually accumulate along with the food chain, which mainly induce various liver disease as a threat to animal and human life by inhibiting the function of protein phosphatases 1 and 2A (Mecina et al., 2019). So it is essential and representative to explore superior strategies for managing the outbreak of $M$. aeruginosa.

A. philoxeroides is a pernicious invasive weed in China, first appeared in South America, and as an amphibious plant, the extraction and release of allelochemicals may provide more opportunities for algae treatments, which has aroused our interests (Prabakaran et al., 2019). Whenever it invades a strange environment, A. philoxeroides occupies the ecological niche quickly and becomes the dominant species in the community, leading to the decline of biodiversity and the destruction of ecological balance (Portela et al., 2020). It has been reported that A. philoxeroides has certain edible and medicinal value in Southeast Asia, but it is generally harmful in most areas with a poor utilization (Masoodi et al., 2013). The reasonable application of A. philoxeroides to algae elimination may weaken algae breed potential and improve its own usage rate at the same time to achieve mutual benefit. Many studies have confirmed the allelopathy of $A$. philoxeroides on other plants (Zoysia matrella, Medicago sativa, Cichoriumintybus, and Avena sativa), ethyl propionate has been found to be one of the main allelochemicals in root extract of $A$. philoxeroides due to its higher content, in addition, the common effect substances may also include diethyl phthalate, dibutyl phthalate etc. (Huang et al., 2017), and some experiments have begun to take notice of its inhibition effect on M. aeruginosa. The discussion was mainly focused on the effects on photosynthesis and antioxidant activities, and there was no relatively systematic research in the aspect of inhibition and stress response of algae. Moreover, the employ of plant-derived compounds has both positive and negative effects, the extraction of some plant-derived compounds involves organic solvents and poses environmental risks, and overuse may affect the biological survival of the original habitat. So it is needed to further evaluate the amount of input in practical application (Suzuki et al., 2020).

Hence, in our experiment, $M$. aeruginosa was selected as the research object, and the allelopathy effects on $M$. aeruginosa were investigated with different concentrations of 
A. philoxeroides extracts, from the following aspects: (a) the influence of $A$. philoxeroides extracts on the biomass of $M$. aeruginosa; (b) impacts of $A$. philoxeroides on physiological and biochemical characteristics of $M$. aeruginosa, oxygen radical, MDA, nucleic acid, microcystin and polysaccharide content were detected; (c) morphology and structure changes of $M$. aeruginosa under $A$. philoxeroides disposition (microscopic observation). We intend to develop a novel environment-friendly algagrowth inhibitor. We also want to supply scientific and theoretical basis for turning this invasive plant into a resource.

\section{Materials and methods}

\section{Test materials}

M. aeruginosa was purchased from the freshwater algae seed bank of the institute of aquatic biology, Chinese Academy of Science (PCC7806). The alga was cultivated in a climate chamber until they were in their logarithmic growth phase. A. philoxeroides used in the experiment was collected at the Zheshan campus lawn of Anhui Normal University, Wuhu, in eastern China $\left(31^{\circ} 34^{\prime} \mathrm{N}, 118^{\circ} 38^{\prime} \mathrm{E}\right)$.

\section{Methods}

\section{Algae cultivation}

$100 \mathrm{~mL}$ of $M$. aeruginosa stock was cultivated with the BG-11 culture medium at $25 \pm 1{ }^{\circ} \mathrm{C}, 4,000 \mathrm{~lx}$, and $12 \mathrm{~h}: 12 \mathrm{~h}$ day light photoperiod for ten days. Fresh culture medium was supplemented and the culture container was shaken 3-4 times per day until $M$. aeruginosa was in its logarithmic growth phase.

The composition of BG-11 medium included $\mathrm{NaNO}_{3} 1.5 \mathrm{~g} / \mathrm{L}, \mathrm{K}_{2} \mathrm{HPO}_{4} 40 \mathrm{mg} / \mathrm{L}$, $\mathrm{MgSO}_{4} 75 \mathrm{mg} / \mathrm{L}, \mathrm{CaCl}_{2} \cdot 2 \mathrm{H}_{2} \mathrm{O} 36 \mathrm{mg} / \mathrm{L}$, Ammonium ferric citrate $6 \mathrm{mg} / \mathrm{L}$, EDTA-2Na 1 $\mathrm{mg} / \mathrm{L}, \mathrm{Na}_{2} \mathrm{CO}_{3} 20 \mathrm{mg} / \mathrm{L}, \mathrm{A} 5+\mathrm{Co}$ (mother liquor) $1 \mathrm{mg} / \mathrm{L}$. Among them, mother liquor formula was $\mathrm{MnCl}_{2} \cdot 4 \mathrm{H}_{2} \mathrm{O} 1.81 \mathrm{~g} / \mathrm{L}, \mathrm{ZnSO}_{4} \cdot 7 \mathrm{H}_{2} \mathrm{O} 0.22 \mathrm{~g} / \mathrm{L}, \mathrm{Na}_{2} \mathrm{MoO}_{4} \cdot 2 \mathrm{H}_{2} \mathrm{O} 0.39 \mathrm{~g} / \mathrm{L}$, $\mathrm{CuSO}_{4} \cdot 5 \mathrm{H}_{2} \mathrm{O} 0.079 \mathrm{~g} / \mathrm{L}, \mathrm{Co}\left(\mathrm{NO}_{3}\right)_{2} \cdot 6 \mathrm{H}_{2} \mathrm{O} 0.049 \mathrm{~g} / \mathrm{L}$.

\section{Extracts preparation}

Fresh A. philoxeroides plant was collected and was first rinsed with tap water, then washed three times with distilled water. Roots, stems and leaves of A. philoxeroides were sampled separately and dried (15-30 min at $105^{\circ} \mathrm{C}$, and then dried to constant weight at $\left.60-70{ }^{\circ} \mathrm{C}\right)$. Each plant part was grounded with a grinder until sufficient amount was available for the experiment. The powder of $40 \mathrm{~g}$ was soaked in $200 \mathrm{~mL}$ distilled water at a ratio of 1:5 (W/V) for $48 \mathrm{~h}$, and then qualitative filter paper and quantitative filter paper were used for double filtration. Final concentration of the filtered solution was considered as $200 \mathrm{~g} / \mathrm{L}$. The concentrations of aqueous extracts were adjusted to 0.3, 0.5, 0.7, 0.9, 1.1 $\mathrm{g} / \mathrm{L}$ by dilution with distilled water and stored at $4{ }^{\circ} \mathrm{C}$ prior to experiment.

\section{Algae growth inhibition test}

$100 \mathrm{~mL}$ of $M$. aeruginosa was transferred to $250 \mathrm{~mL}$ sterilized conical flask. Initial concentration of these algae was $1.43 \times 10^{6}$ cells $/ \mathrm{mL}$. Different concentrations of the root, stem and leaf extracts $(0,0.3,0.5,0.7,0.9,1.1 \mathrm{~g} / \mathrm{L})$ were then added to conical flasks containing $M$. aeruginosa. Since only a small amount of the extract was added to 
each conical flask, there was little effect on algal density, so extract volume was not considered. The test was replicated three times. The number of algal cells was counted with a blood cell counter once every $24 \mathrm{~h}$ and recorded to $96 \mathrm{~h}$.

The growth inhibition rate of $M$. aeruginosa by the extracts of A. philoxeroides was calculated as the following formula:

$$
I R(\%)=(1-N 1 / N o) \times 100 \%
$$

where $N 1$ represents the algae density in the treatment group at day $N$, while $N O$ represents the algae density in the control group at day $N$. Units of both $N 1$ and $N O$ are cell counts $/ \mathrm{mL}$.

\section{Determination of physiological parameters of M. aeruginosa}

Nucleic acid, MDA and $\mathrm{O}_{2}^{-}$were determined at 24, 72 and $120 \mathrm{~h}$ after cultivation. $12 \mathrm{~mL}$ algae solution was collected and centrifuged at 4,000 r/min for $10 \mathrm{~min}$. The supernatant was used to measure the content of nuclear acid using UV-Vis spectrophotometer (UV-3802, Unico, USA) at $260 \mathrm{~nm}$ (Sun et al., 2004). The sediment was dissolved in $1 \mathrm{~mL}$ phosphate buffer saline (PBS) ( $\mathrm{pH} 7.0$ ), for three times of repeated freeze-thaw at $-80^{\circ} \mathrm{C}$. After centrifugation at $12,000 \mathrm{r} / \mathrm{min}$ for $15 \mathrm{~min}$, the supernatant was the enzyme solution of MDA. $2 \mathrm{~mL}$ enzyme solution (control plus $2 \mathrm{~mL}$ distilled water) was added to $2 \mathrm{~mL} \mathrm{10 \%} \mathrm{trichloroacetic} \mathrm{acid} \mathrm{(TCA)} \mathrm{containing} 0.5 \%$ thiobarbituric acid (TBA). The mixture was placed in a boiling water bath at $100{ }^{\circ} \mathrm{C}$ for $15 \mathrm{~min}$, cooled rapidly and then placed in a centrifuge at 4,000 r/min for $10 \mathrm{~min}$. The supernatant was taken and the absorbance was measured at 450, 532 and $600 \mathrm{~nm}$ respectively. MDA $(\mathrm{umol} / \mathrm{g})=6.45 \times(\mathrm{A} 532-\mathrm{A} 600)-0.56 \times \mathrm{A} 450$. In the determination of $\mathrm{O}_{2}{ }^{-}$content, $2 \mathrm{~mL}$ supernatant of algal liquid was taken with the same centrifugation at 4,000 r/min for 10 min, and $0.4 \mathrm{~mL} 10 \mathrm{mmol} / \mathrm{L}$ hydroxylamine hydrochloride was added. After mixing, the supernatant was placed in a water bath at $25^{\circ} \mathrm{C}$ for $20 \mathrm{~min}$. Then $2 \mathrm{~mL} \alpha$-naphthylamine $(7 \mathrm{mmol} / \mathrm{L})$ and $2 \mathrm{~mL} \mathrm{p}$-aminobenzene sulfonic acid $(17 \mathrm{mmol} / \mathrm{L})$ were added, mixed and the reaction was carried out at $25^{\circ} \mathrm{C}$ for $25 \mathrm{~min}$. The same volume of butyl alcohol was used, shaken thoroughly and the reaction mixture was set aside for layering. The upper butyl alcohol was taken to measure the light absorption value at $530 \mathrm{~nm}$.

At $72 \mathrm{~h}, 20 \mathrm{~mL}$ algae solution was collected and centrifuged at 4,000 r/min for $15 \mathrm{~min}$, the supernatant was transferred to Eppendorf tube and saved at $-20{ }^{\circ} \mathrm{C}$ for the determination of extracellular polysaccharides and microcystins in $M$. aeruginosa. The sediment was transferred with $1 \mathrm{~mL}$ PBS ( $\mathrm{pH}$ 7.2-7.4), repeated freeze-thaw was carried out at $-20{ }^{\circ} \mathrm{C}$ for 3 times, then the supernatant was taken and stored at $-20{ }^{\circ} \mathrm{C}$ for determination of intracellular polysaccharides and microcystins in $M$. aeruginosa. Both microcystins and polysaccharides were analyzed by enzyme-linked immunosorbent assay (ELISA) kit (96T/48T, Shanghai Xinyu Biotechnology Co., Ltd), and the specific operation method was referred to the kit instructions.

\section{Observation of cell superficial structure of M. aeruginosa}

The algae cells treated with root extracts of different concentrations for $72 \mathrm{~h}$ were collected, fixed with $2.5 \%$ glutaraldehyde for $24 \mathrm{~h}$ and $1 \%$ osmium acid for $1 \mathrm{~h}$, and then washed with PBS ( $\mathrm{pH} 7.4$ ) for 3 times. The ethanol gradients of $15 \%, 30 \%, 50 \%$, $75 \%, 95 \%$ and $100 \%$ were used to elute for 15 min respectively. After the supernatant 
was discarded, $10 \mathrm{~mL} \mathrm{1:1} \mathrm{mixture} \mathrm{of} \mathrm{isoamyl} \mathrm{acetate} \mathrm{and} \mathrm{ethanol} \mathrm{was} \mathrm{added} \mathrm{and} \mathrm{soaked}$ for 10-20 min. The sediment left by centrifugation was further soaked and shaken in pure isoamyl acetate for $20 \mathrm{~min}$, and then observed and photographed under a scanning electron microscope (JSM-6390LV, JEOL) after coating.

\section{Data analysis}

The obtained data were expressed in terms of mean value \pm SE (standard error), and SPSS 19.0 analysis software was used to analyze the differences between the control group and treatment group for one-way ANOVA followed by a T-test. P $<0.05$ represents statistical significance, and $\mathrm{P}<0.01$ represents a greater significant difference.

\section{Results and analyses}

\section{Effects of A. philoxeroides extracts on M. aeruginosa growth}

When $M$. aeruginosa was exposed to the extracts of root, stem and leaf from $A$. philoxeroides for $24 \mathrm{~h}, 48 \mathrm{~h}, 72 \mathrm{~h}$ and $96 \mathrm{~h}$, the growth inhibition rate of algal cells increased with increasing concentration of extracts (Table 1). In particular, when $M$. aeruginosa was treated for $24 \mathrm{~h}$ by $\geq 0.5 \mathrm{~g} / \mathrm{L}$ root extract, $\geq 0.7 \mathrm{~g} / \mathrm{L}$ stem extract and $\geq 0.5 \mathrm{~g} / \mathrm{L}$ leaf extract from $A$. philoxeroides, significant differences generated compared with lower concentration treatments $(\mathrm{P}<0.05)$. Also, during the entire experimental process, the growth inhibition rate of each treatment group showed an obvious trend of increasing with culture time. After $96 \mathrm{~h}$ exposure, the optimal concentration of root extract with the highest growth inhibition was $0.9 \mathrm{~g} / \mathrm{L}$, the IR was close to $80.48 \%$, while the optimal concentrations of stem and leaf extracts were both $1.1 \mathrm{~g} / \mathrm{L}$, and the IR was $55.79 \%$ and $45.64 \%$, respectively.

Table 1. The effect of A. philoxeroides extracts on M. aeruginosa growth

\begin{tabular}{c|c|c|c|c|c}
\hline \multirow{2}{*}{ Treatment } & \multicolumn{5}{|c}{ Growth inhibition rate (\%) } \\
\cline { 2 - 6 } & Concentration $\mathbf{( g / L )}$ & $\mathbf{2 4} \mathbf{~ h}$ & $\mathbf{4 8} \mathbf{h}$ & $\mathbf{7 2} \mathbf{~ h}$ & $\mathbf{9 6} \mathbf{~}$ \\
\hline \multirow{3}{*}{ Root extract } & 0.3 & $25.22 \pm 1.21 \mathrm{a}$ & $43.61 \pm 1.78 \mathrm{a}$ & $55.72 \pm 2.09 \mathrm{a}$ & $64.42 \pm 1.13 \mathrm{a}$ \\
& 0.5 & $28.11 \pm 1.84 \mathrm{~b}$ & $56.45 \pm 0.65 \mathrm{~b}$ & $57.46 \pm 1.04 \mathrm{~b}$ & $70.05 \pm 2.36 \mathrm{a}$ \\
& 0.7 & $34.62 \pm 1.47 \mathrm{c}$ & $63.37 \pm 0.55 \mathrm{c}$ & $66.53 \pm 1.35 \mathrm{c}$ & $74.62 \pm 1.76 \mathrm{~b}$ \\
& 0.9 & $51.57 \pm 1.58 \mathrm{~d}$ & $73.07 \pm 1.19 \mathrm{~d}$ & $74.75 \pm 0.33 \mathrm{~d}$ & $80.48 \pm 1.13 \mathrm{c}$ \\
Stem extract & 1.1 & $51.57 \pm 0.87 \mathrm{~d}$ & $72.95 \pm 0.63 \mathrm{~d}$ & $74.70 \pm 0.32 \mathrm{~d}$ & $80.34 \pm 1.18 \mathrm{c}$ \\
\hline & 0.3 & $29.96 \pm 3.32 \mathrm{a}$ & $23.67 \pm 0.45 \mathrm{a}$ & $32.33 \pm 1.01 \mathrm{a}$ & $43.61 \pm 0.97 \mathrm{a}$ \\
& 0.5 & $30.60 \pm 0.72 \mathrm{a}$ & $23.67 \pm 1.06 \mathrm{a}$ & $35.19 \pm 0.20 \mathrm{~b}$ & $47.53 \pm 0.73 \mathrm{~b}$ \\
& 0.7 & $42.97 \pm 4.87 \mathrm{~b}$ & $38.98 \pm 0.45 \mathrm{~b}$ & $45.57 \pm 1.21 \mathrm{c}$ & $52.15 \pm 0.52 \mathrm{c}$ \\
& 0.9 & $42.81 \pm 0.91 \mathrm{~b}$ & $45.66 \pm 1.82 \mathrm{c}$ & $49.07 \pm 1.06 \mathrm{~d}$ & $54.91 \pm 0.56 \mathrm{~d}$ \\
& 1.1 & $51.08 \pm 1.05 \mathrm{c}$ & $48.31 \pm 0.96 \mathrm{~d}$ & $51.66 \pm 0.62 \mathrm{e}$ & $55.79 \pm 1.67 \mathrm{~d}$ \\
\hline \multirow{3}{*}{ Leaf extract } & 0.3 & $13.33 \pm 6.06 \mathrm{a}$ & $10.03 \pm 2.16 \mathrm{a}$ & $20.58 \pm 1.05 \mathrm{a}$ & $31.61 \pm 0.83 \mathrm{a}$ \\
& 0.5 & $25.65 \pm 2.64 \mathrm{~b}$ & $30.90 \pm 0.45 \mathrm{~b}$ & $32.27 \pm 0.31 \mathrm{~b}$ & $35.44 \pm 0.92 \mathrm{~b}$ \\
& 0.7 & $38.88 \pm 1.24 \mathrm{c}$ & $34.22 \pm 0.48 \mathrm{c}$ & $36.46 \pm 0.45 \mathrm{c}$ & $38.81 \pm 1.18 \mathrm{c}$ \\
& 0.9 & $42.01 \pm 0.37 \mathrm{c}$ & $40.66 \pm 1.88 \mathrm{~d}$ & $41.53 \pm 0.77 \mathrm{~d}$ & $42.96 \pm 1.18 \mathrm{~d}$ \\
& 1.1 & $42.25 \pm 1.24 \mathrm{c}$ & $44.04 \pm 0.28 \mathrm{e}$ & $44.78 \pm 0.22 \mathrm{e}$ & $45.64 \pm 0.62 \mathrm{e}$ \\
\hline
\end{tabular}

Data in the table are mean value $(n=3) \pm$ SE. Different letters in the same column indicate significant difference among treatments of different concentrations of extracts from the same plant part at $\mathrm{P}<0.05$, while the same letters indicate no significant difference within the treatment (plant organs) 


\section{Effects of A. philoxeroides extracts on nucleic acid contents in M. aeruginosa}

As shown in Table 2, a series of diluted extracts from various organs of $A$. philoxeroides had different effects on the nucleic acid release of $M$. aeruginosa. Among them, after $24 \mathrm{~h}, 72 \mathrm{~h}$ and $120 \mathrm{~h}$ culture, the nucleic acid content of the treated group was significantly higher than that of the control group when the concentration of root extract was $\geq 0.3 \mathrm{~g} / \mathrm{L}$, stem extract was $\geq 0.5 \mathrm{~g} / \mathrm{L}, \geq 0.3 \mathrm{~g} / \mathrm{L}, \geq 0.5 \mathrm{~g} / \mathrm{L}$, and leaf extract was $\geq 0.7 \mathrm{~g} / \mathrm{L}, \geq 0.5 \mathrm{~g} / \mathrm{L}, \geq 0.5 \mathrm{~g} / \mathrm{L}$ ( $\mathrm{P}<0.05)$. And nucleic acid content was the highest after $120 \mathrm{~h}$ treatment when the concentration of root, stem and leaf extracts was $1.1 \mathrm{~g} / \mathrm{L}$, which was increased by $96.94 \%, 62.14 \%$ and $51.82 \%$ respectively compared to that in the control group. $M$. aeruginosa cells exhibited the most nucleic acid release in the root extract treatment group, followed by the stem and leaf extract treatment groups with the same concentration.

Table 2. Effects of A. philoxeroides extracts on nucleic acid content of M. aeruginosa

\begin{tabular}{c|c|c|c|c}
\hline \multirow{2}{*}{ Treatment } & \multicolumn{4}{|c}{ Nucleic acid content $\left(\mathbf{O D}_{\mathbf{2 6 0}}\right)$} \\
\cline { 2 - 5 } & Concentration $\mathbf{( g / L )}$ & $\mathbf{2 4} \mathbf{h}$ & $\mathbf{7 2 ~ h}$ & $\mathbf{1 2 0} \mathbf{~ h}$ \\
\hline Control & 0 & $0.0773 \pm 0.0031 \mathrm{a}$ & $0.0823 \pm 0.0025 \mathrm{a}$ & $0.0872 \pm 0.0031 \mathrm{a}$ \\
\hline \multirow{3}{*}{ Root extract } & 0.3 & $0.0850 \pm 0.0026 \mathrm{~b}$ & $0.1177 \pm 0.0015 \mathrm{~b}$ & $0.1307 \pm 0.0015 \mathrm{~b}$ \\
& 0.5 & $0.0857 \pm 0.0040 \mathrm{~b}$ & $0.1233 \pm 0.0021 \mathrm{c}$ & $0.1363 \pm 0.0025 \mathrm{c}$ \\
& 0.7 & $0.0913 \pm 0.0012 \mathrm{c}$ & $0.1143 \pm 0.0040 \mathrm{~d}$ & $0.1580 \pm 0.0026 \mathrm{~d}$ \\
& 0.9 & $0.1323 \pm 0.0021 \mathrm{~d}$ & $0.1600 \pm 0.0020 \mathrm{e}$ & $0.1680 \pm 0.0020 \mathrm{e}$ \\
Stem extract & 1.1 & $0.1303 \pm 0.0025 \mathrm{~d}$ & $0.1613 \pm 0.0021 \mathrm{e}$ & $0.1717 \pm 0.0021 \mathrm{e}$ \\
\hline & 0.3 & $0.0770 \pm 0.0017 \mathrm{a}$ & $0.0870 \pm 0.0021 \mathrm{~b}$ & $0.1037 \pm 0.0021 \mathrm{a}$ \\
& 0.5 & $0.0883 \pm 0.0021 \mathrm{~b}$ & $0.1023 \pm 0.0025 \mathrm{c}$ & $0.1157 \pm 0.0012 \mathrm{~b}$ \\
& 0.7 & $0.0913 \pm 0.0031 \mathrm{~b}$ & $0.1117 \pm 0.0031 \mathrm{~d}$ & $0.1270 \pm 0.0030 \mathrm{c}$ \\
& 0.9 & $0.0917 \pm 0.0035 \mathrm{~b}$ & $0.1210 \pm 0.0026 \mathrm{e}$ & $0.1370 \pm 0.0020 \mathrm{~d}$ \\
& 1.1 & $0.1000 \pm 0.0010 \mathrm{c}$ & $0.1277 \pm 0.0021 \mathrm{f}$ & $0.1413 \pm 0.0015 \mathrm{e}$ \\
\hline \multirow{3}{*}{ Leaf extract } & 0.3 & $0.0753 \pm 0.0014 \mathrm{a}$ & $0.0847 \pm 0.0015 \mathrm{a}$ & $0.1010 \pm 0.0030 \mathrm{ab}$ \\
& 0.5 & $0.0797 \pm 0.0012 \mathrm{ab}$ & $0.0927 \pm 0.0025 \mathrm{~b}$ & $0.1083 \pm 0.0025 \mathrm{~b}$ \\
& 0.7 & $0.0833 \pm 0.0012 \mathrm{~b}$ & $0.1037 \pm 0.0025 \mathrm{c}$ & $0.1173 \pm 0.0021 \mathrm{c}$ \\
& 0.9 & $0.0893 \pm 0.0015 \mathrm{c}$ & $0.1163 \pm 0.0021 \mathrm{~d}$ & $0.1297 \pm 0.0071 \mathrm{~d}$ \\
\hline
\end{tabular}

Data in the table are mean value $(n=3) \pm$ SE. Different letters in the same column indicate significant difference among treatments of different concentrations of extracts from the same plant part at $\mathrm{P}<0.05$, while the same letters indicate no significant difference within the treatment (plant organs)

\section{Effect of A. philoxeroides extracts on $\mathrm{O}_{2}^{-}$contents in M. aeruginosa}

After the treatment of $M$. Aeruginosa with root, stem and leaf extracts of different concentrations for $24 \mathrm{~h}, 72 \mathrm{~h}$ and $120 \mathrm{~h}$, the $\mathrm{O}_{2}{ }^{-}$content in the treatment group increased with the rise of extract concentrations, and with the extension of culture time, the $\mathrm{O}_{2}{ }^{-}$ content in algal cells of the treatment group reached a significant higher level than the control group at a lower extract concentration (Fig. 1). Of which, under $120 \mathrm{~h}$ exposure, significant differences appeared at the concentration ranges of root extract $\geq 0.3 \mathrm{~g} / \mathrm{L}$, stem extract $\geq 0.3 \mathrm{~g} / \mathrm{L}$ and leaf extract $\geq 0.5 \mathrm{~g} / \mathrm{L}(\mathrm{P}<0.05) . \mathrm{O}_{2}{ }^{-}$content attained the highest value when the extracts of root, stem and leaf was $1.1 \mathrm{~g} / \mathrm{L}$, which was $2.67,1.96$ 
and 1.83 times higher than the control group, respectively. Besides, according to our results, root extract had the most powerful effect on the induction of $\mathrm{O}_{2}^{-}$in $M$. aeruginosa, followed by stem and leaf extract, respectively.

a
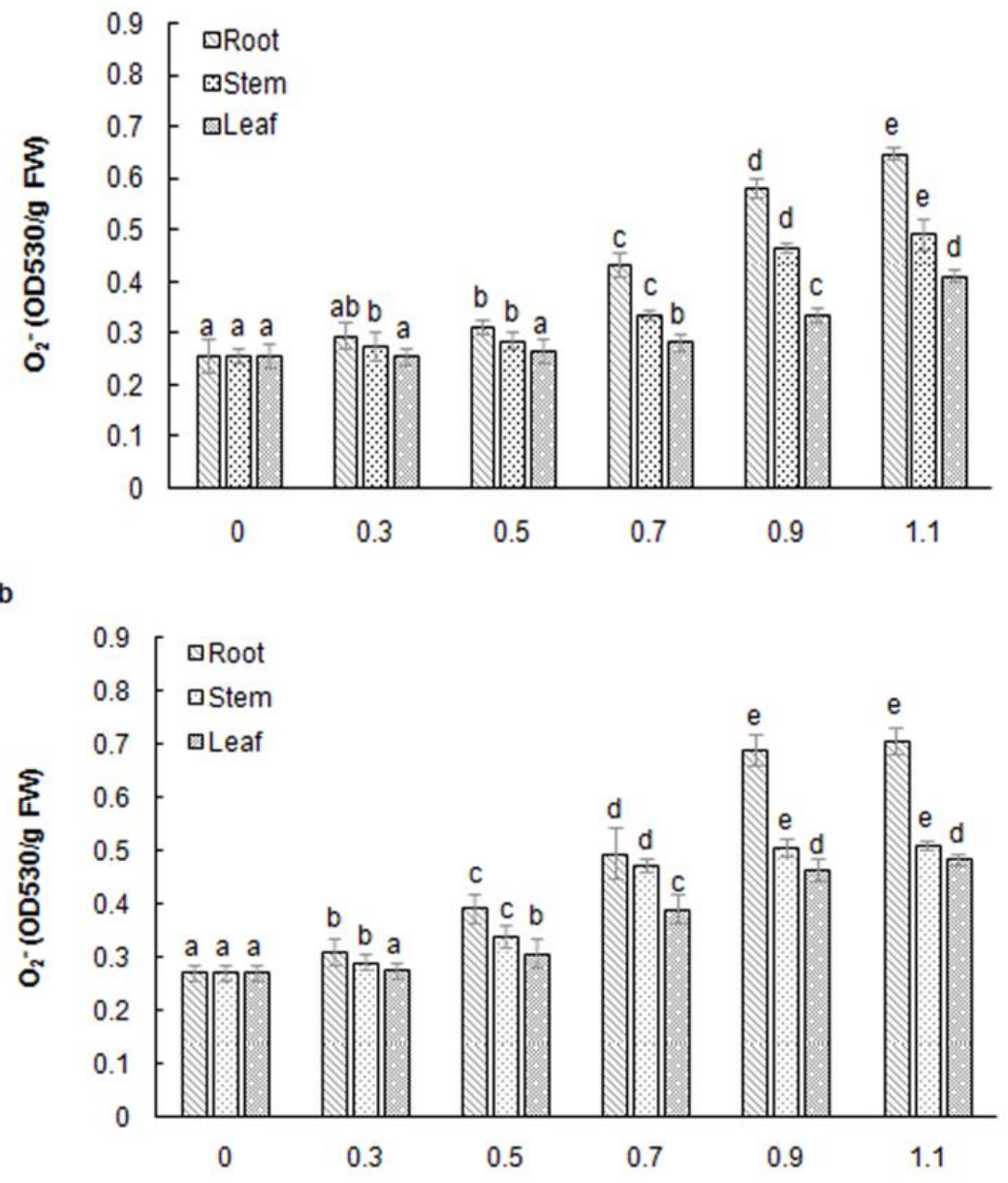

c

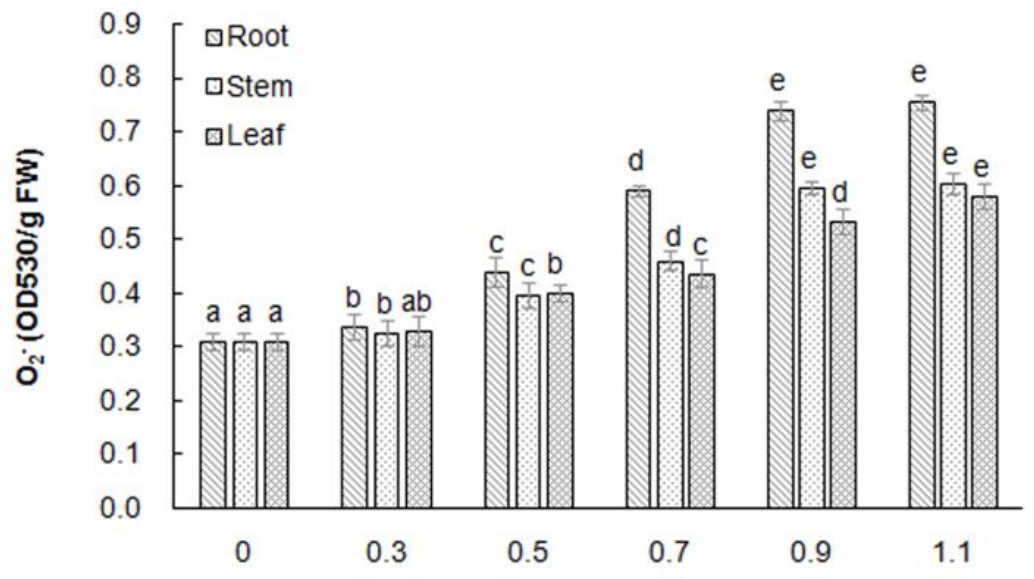

Figure 1. $\mathrm{O}_{2}{ }^{-}$contents in $M$. aeruginosa exposed to different concentrations of A. philoxeroides extracts for $24 h(a), 72 h(b)$ and $120 h(c)$. Mean values $(n=3)$ followed by different letters represent significant difference in treatments of different extract concentrations from the same plant part at $P<0.05$; otherwise, the same letters represent no significant difference 


\section{Effect of A. philoxeroides extracts on MDA contents in M. aeruginosa}

The MDA content of $M$. aeruginosa treated with extracts from A. philoxeroides for $24 \mathrm{~h}$, $72 \mathrm{~h}$ and $120 \mathrm{~h}$ overall increased with increasing concentration of extracts. In particular, after $24 \mathrm{~h}$ exposure, MDA content decreased initially (from 0 to $0.3 \mathrm{~g} / \mathrm{L}$ ) in all treatments and was significantly increased when $M$. aeruginosa cells were treated by $\geq 0.5 \mathrm{~g} / \mathrm{L}$ root, stem extracts and $\geq 0.7 \mathrm{~g} / \mathrm{L}$ leaf extract $(\mathrm{P}<0.05)$, finally reached the peak at $1.1 \mathrm{~g} / \mathrm{L}$ (Fig. $2 a)$. However, after $120 \mathrm{~h}$ exposure, MDA content in the treatment group was significantly higher than that in the control group from the beginning with $0.3 \mathrm{~g} / \mathrm{L}$ extracts $(\mathrm{P}<0.05)$ and elevated continually (Fig. 2c). In addition, beneath high concentration for a long time, the allelopathy of three extracts from A. philoxeroides showed the following sequence: root $>$ stem $>$ leaf, the effect of root extract on MDA contents in M. aeruginosa was the most obvious.

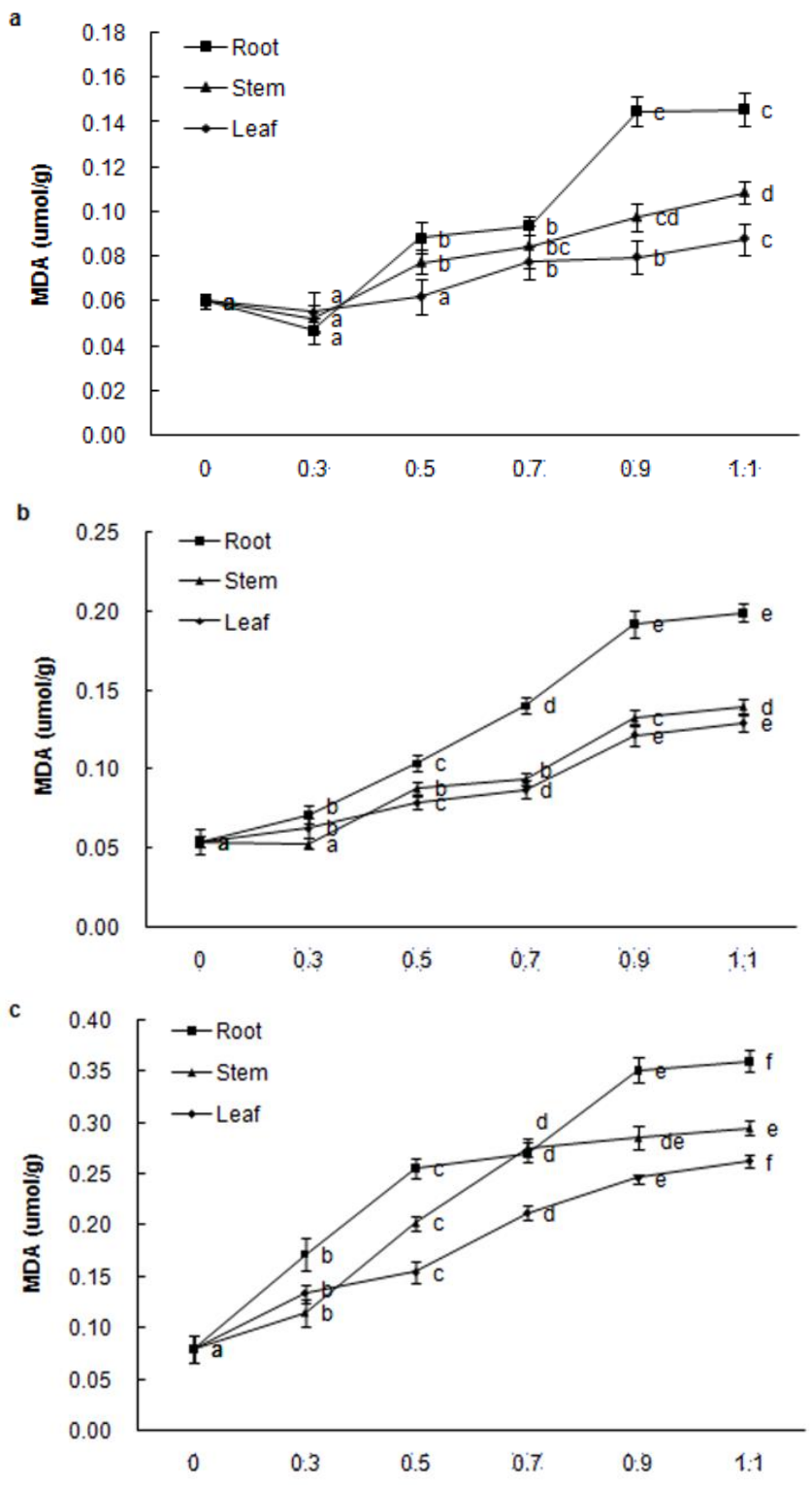

Figure 2. MDA content in M. aeruginosa cells exposed to different concentrations of A. philoxeroides extracts for $24 h(a), 72 h(b)$, and $120 h(c)$. Mean values $(n=3)$ followed by different letters represent significant difference in treatments of different extract concentrations from the same plant part at $P<0.05$; otherwise, the same letters represent no significant difference 


\section{Effects of A. philoxeroides on intracellular and extracellular microcystin contents in M. aeruginosa}

The release of microcystins in $M$. aeruginosa at different concentrations of extracts from A. philoxeroides showed a similar growth situation as above (Fig. 3). In general, the intracellular and extracellular content of microcystins in the treatment group was significantly higher than that in the control group when $M$. aeruginosa cells were treated by $\geq 0.3 \mathrm{~g} / \mathrm{L}$ root extract, $\geq 0.5 \mathrm{~g} / \mathrm{L}$ stem extract and $\geq 0.5 \mathrm{~g} / \mathrm{L}$ leaf extract, or $\geq 0.3 \mathrm{~g} / \mathrm{L}$ of all kinds of extracts respectively $(\mathrm{P}<0.05) .1 .1 \mathrm{~g} / \mathrm{L}$ of root, stem and leaf extracts had the most adverse stimulation, that is intracellular (by $57.70 \%, 23.00 \%$ and $13.05 \%$ ) and extracellular (by $62.82 \%, 47.50 \%$ and $38.65 \%$ ) microcystins had the largest increase compared to the control. Under different treatments, the extracellular content of microcystins released by $M$. aeruginosa cells was always lower than that in the intracellular. And according to the consequences, it could be intuitively reflected that the restrain to algal cells from strong to weak was root, stem and leaf extracts.

a

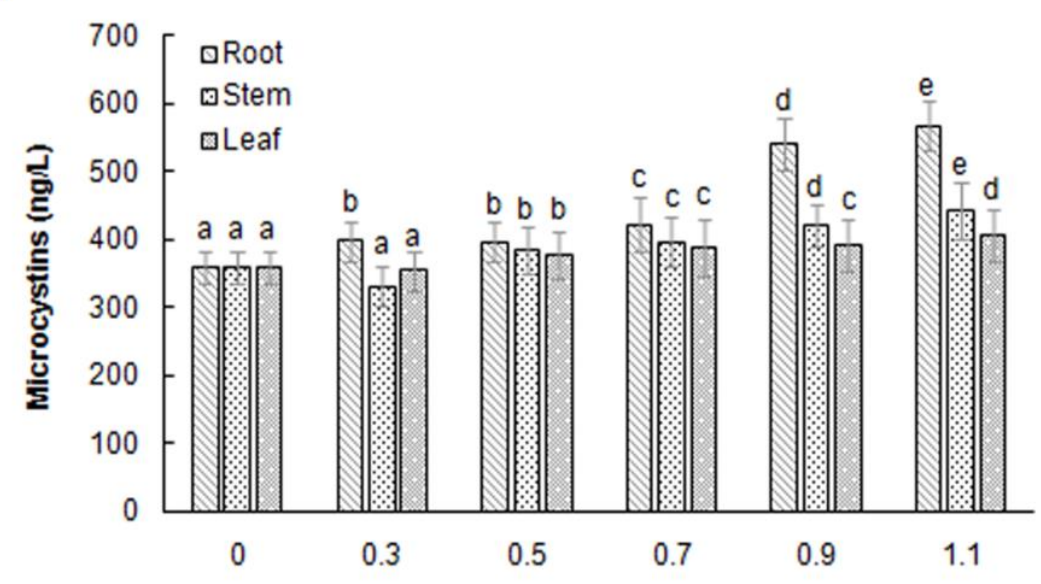

b

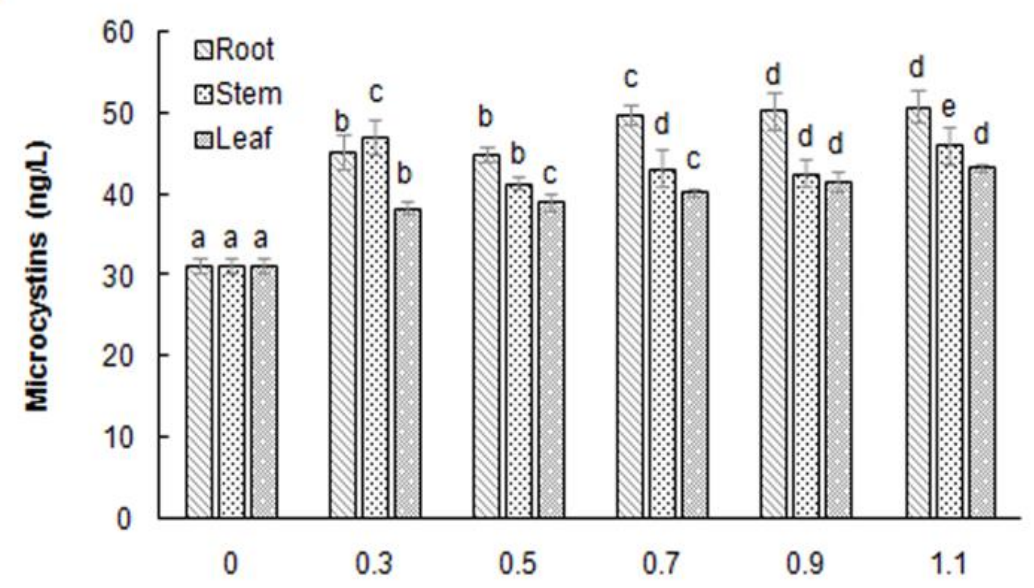

Figure 3. Effects of extracts from A. philoxeroides on intracellular (a) and extracellular (b) microcystin contents in M. aeruginosa. Mean values $(n=3)$ followed by different letters represent significant difference in treatments of different extract concentrations from the same plant part at $P<0.05$; otherwise, the same letters represent no significant difference 


\section{Effects of A. philoxeroides on intra- and extra-cellular polysaccharide contents in $M$. aeruginosa}

The results showed that both intra- and extra-cellular contents of polysaccharides in $M$. aeruginosa increased with increasing concentration of extracts, and the content of extracellular polysaccharides was relatively high (Fig. 4). After $72 \mathrm{~h}$ exposure of $M$. aeruginosa to $\geq 0.3 \mathrm{~g} / \mathrm{L}$ of root, stem and leaf extracts, the intracellular content of polysaccharides in the treatment group was significantly higher than that in the control group $(\mathrm{P}<0.05)$. While extracellular content of polysaccharides achieved significant differences when $M$. aeruginosa cells were exposed to $\geq 0.3 \mathrm{~g} / \mathrm{L}$ root extract, $\geq 0.3 \mathrm{~g} / \mathrm{L}$ stem extract and $\geq 0.7 \mathrm{~g} / \mathrm{L}$ leaf extract $(\mathrm{P}<0.05)$. The action strength of the extracts from A. philoxeroides was root $>$ stem $>$ leaf, and $1.1 \mathrm{~g} / \mathrm{L}$ had the greatest influence on the production of polysaccharides in $M$. philoxeroides.

a

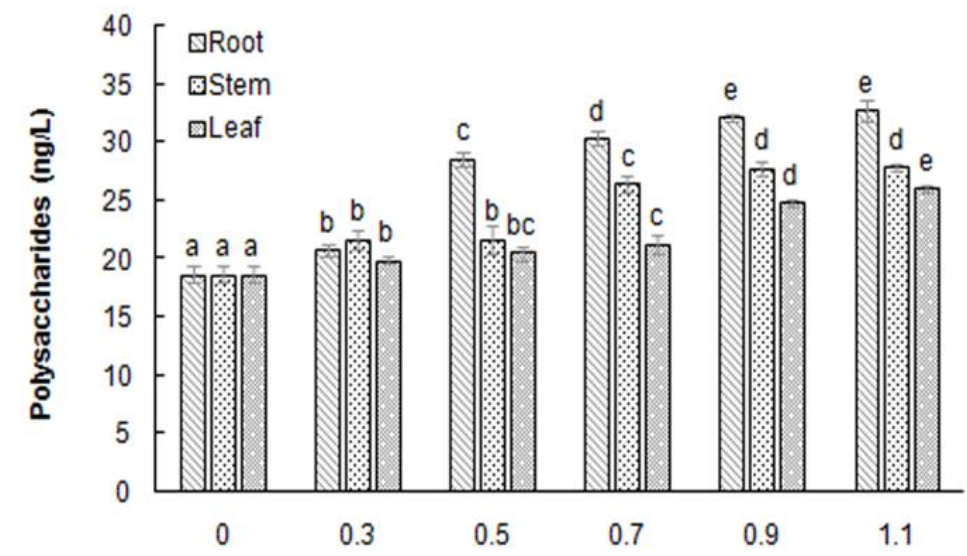

b

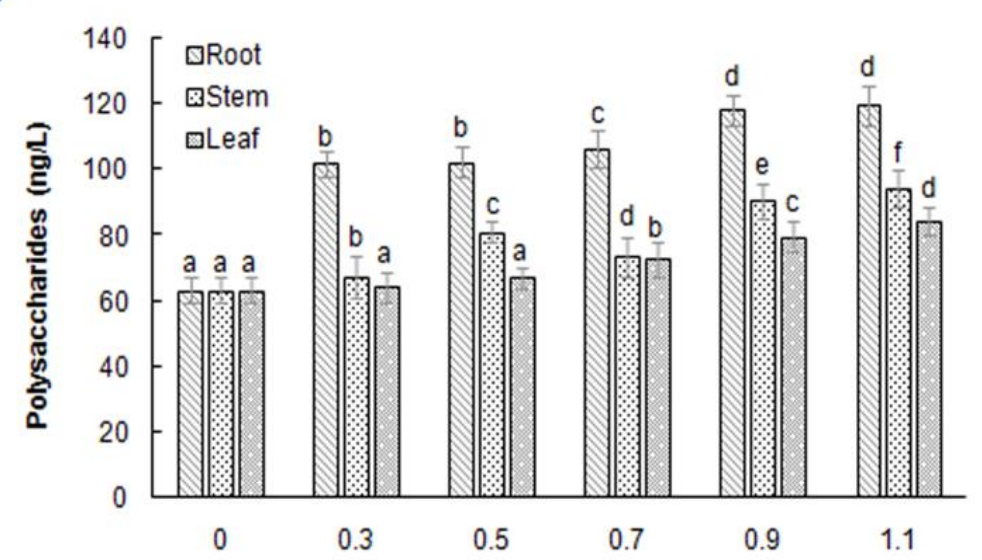

Figure 4. Effects of extracts from A. philoxeroides on intracellular (a) and extracellular (b) polysaccharide contents in M. aeruginosa. Mean values $(n=3)$ followed by different letters represent significant difference in treatments of different extract concentrations from the same plant part at $P<0.05$; otherwise, the same letters represent no significant difference

\section{Effect of A. philoxeroides on cell superficial structure of M. aeruginosa}

It was observed by scanning electron microscope that the $M$. aeruginosa cells in the control group remained their integrity with a round and smooth appearance, while the 
surface structure of $M$. aeruginosa cells in the treatment group was severely damaged after being exposed to root extract from A. philoxeroides for $72 \mathrm{~h}$ (Fig. 5). With the increasing concentrations of root extract, the morphology of $M$. aeruginosa cells changed gradually, cell shrank, cell wall ruptured and intracellular material flowed out until the cell disintegrated. The $1.1 \mathrm{~g} / \mathrm{L}$ of root extract was the most destructive on the structure of M. aeruginosa cells.
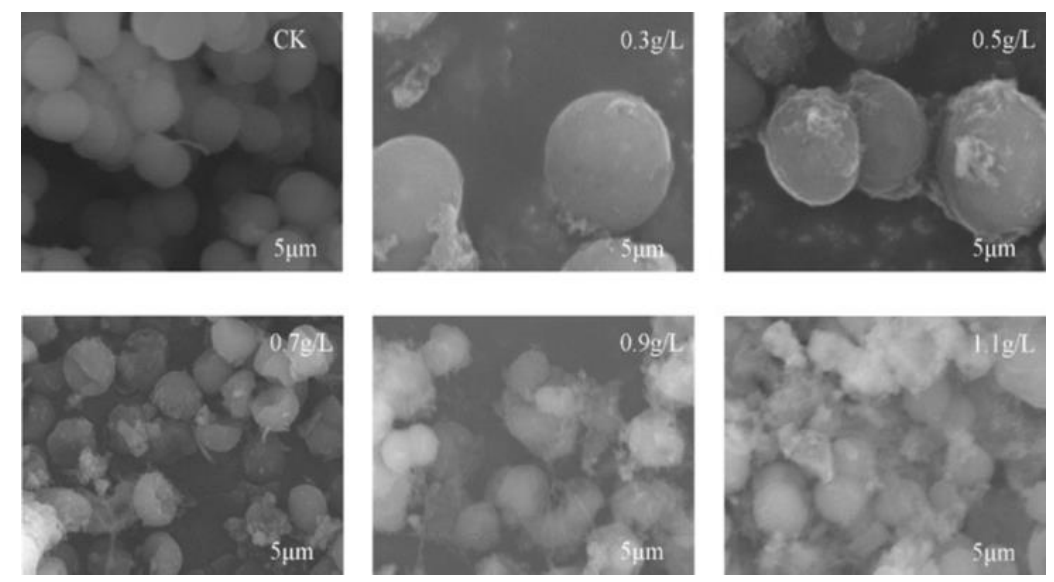

Figure 5. Scanning electron microscope images of cell morphology and structure of $M$. aeruginosa damaged by root extract $(0-1.1 \mathrm{~g} / \mathrm{L})$ from A. philoxeroides $(\times 5000)$

\section{Discussion}

Recent research has found that the growth of $M$. aeruginosa was inhibited by the root, stem and leaf extracts from A. philoxeroides. In general, the inhibition intensity was weak at low concentrations and increased at high concentrations, that is the growth of algae was greatly restricted. The same inhibitory trend was also found in the study of Li et al. (2016) about Sagittaria trifolia tubers extract influence on M. aeruginosa. After being treated with $0.9 \mathrm{~g} / \mathrm{L}$ root extract for $96 \mathrm{~h}$, the growth inhibition rate of $M$. aeruginosa cells was $80.48 \%$ (Table 1), which showed that M. aeruginosa cells could hardly survive in this environment. Scanning electron microscopy (SEM) displayed that the algae cells were damaged in varying degrees with the increase of the concentration of root extract for $72 \mathrm{~h}$ (Fig. 5), which means the extracts of A. philoxeroides could inhibit cell growth by destroying the morphological structure of $M$. aeruginosa cells, promoting cell lysis and finally leading to cell death. As one type of small molecules, nucleic acid is normally enclosed in the cell. Sometimes, on account of adverse stimulus, the cell membrane cannot maintain the relative stability of the internal structure and function of cells, and control the transport of substances inside and outside the cells due to the loss of selective permeability, thus nucleic acid is released (Shi et al., 2018). With the increase of extracts concentration and culture time, the increase of nucleic acid content further verified the damage degree of algal cells (Table 2).

In order to survive in an unfavorable living environment, organisms have evolved a set of strategies to outwit their adversaries. One of them is the antioxidant enzyme system (García et al., 2016). Under normal circumstances, the process of cell metabolism to complete all kinds of life activities can produce reactive oxygen species (ROS). Due to the antioxidant enzymes, cells can effectively fight against the negative impacts of reactive oxygen species and maintain the intracellular ROS level in 
equilibrium (Pereira et al., 2018). Nevertheless, when the cells are subjected to adverse external stimulation (ultraviolet-B, heavy metal and allelochemicals), the original balanced state is broken, and excessive reactive oxygen exists, leading to peroxidation damage of the cells (Zhang and Benoit., 2019).

We found in this study, $\mathrm{O}_{2}^{-}$transformation in $M$. aeruginosa could be affected by $A$. philoxeroides extracts, especially root extract (at $1.1 \mathrm{~g} / \mathrm{L}$ ) with a strong competence. The $\mathrm{O}_{2}{ }^{-}$content in the treatment group was significantly higher than that of the control group after exceeding a certain concentration range and constantly elevated with the extension of culture time (Fig. 1). Huang et al. (2013) also showed the accumulation of intracellular reactive oxygen species in the study of allelopathy of Solidago canadensis L. against $M$. aeruginosa, and pointed out that the response mainly depended on the allelopathic substance released by the plants rather than the plant species. Furthermore, induced accumulation of reactive oxygen species in cells may cause damage to photosynthetic pigment, protein, DNA and lipid (Apel and Hirt, 2004). Algal cell membranes are composed of unsaturated phospholipids and are susceptible to ROS, MDA as one of the products of lipid decomposition, it is usually used to mark the process of membrane lipid peroxidation, and the changes in its concentration can reflect the damage of cell membrane and the ability of cells to resist harmful external interference (Davey et al., 2005). The results indicated that MDA content in $M$. aeruginosa increased gradually, which coincided with the increase of $\mathrm{O}_{2}{ }^{-}$content, but after $24 \mathrm{~h}$ treatment with the root, stem and leaf extracts of $0.3 \mathrm{~g} / \mathrm{L}, \mathrm{MDA}$ content decreased slightly compared with the control group (Fig. 2). Under the stimulation of short time and low concentration of the extracts, stress response occurred in algal cells thus membrane permeability and enzyme activities heightened, which could promote cells to absorb the nutrients contained in the extracts and temporarily maintain cells growth (Yuan et al., 2020). In addition, a small amount of ROS was removed by antioxidant enzymes, and the content of MDA was also decreased. It was needed noting that severe membrane lipid peroxidation would lead to a continuous increase of MDA content as the effect of extracts exceeded the tolerance threshold of algal cells (Chen et al., 2019).

The formation of microcystins (MCs) and polysaccharides (PSs) is thought to be a way for algal cells to maintain their growth and a defense mechanism to fight against adverse external factors. MCs are secondary metabolites produced by $M$. aeruginosa, which are usually trapped in living cells, ROS can transmit signals to cause oxidative stress in algal cells, thus promote the combination of MCs with some specific proteins to regulate self-synthesis and release process (Tsai, 2015). Wu et al. (2013) found that allelochemical extracts of Pistia stratiotes had influences on $M$ aeruginosa, during the whole culture period, high concentration extract had no significant role in the release of extracellular MC contents while the intracellular MC contents increased in a concentration-dependent manner and finally remained stable. Hou et al. (2019) pointed out that the allelopathic inhibition of juglone on $M$. aeruginosa resulted in the increase of both intracellular and extracellular MC contents with the rise of juglone concentration. Our experiment showed the same results with Hou et al. (2019) that intracellular and extracellular MC contents increased in a dose-dependent manner after $72 \mathrm{~h}$ treatment (Fig. 3). The main reason was that membrane lipid peroxidation promoted the production of MCs, and the extracellular MC contents were released gradually with the metabolic activities and life process of the cells. The content changes display a positively interactive effect between intracellular and extracellular MC 
contents (Chen et al., 2015). It was worth saying that the production and release of MCs could be used as an important indicator to evaluate the treatment of algal blooms by allelochemicals. In our study, although the contents of MCs increased gradually in the test, the extracellular MC contents was far less than the intracellular. Especially at high concentration of root extract $(0.9 \mathrm{~g} / \mathrm{L} 96 \mathrm{~h})$, the inhibition rate of algal cells was more than $80 \%$, that is the cell survival rate was low, but most MCs still existed in the cells. In the follow-up research, it is necessary to further isolate and identify allelochemicals that play a major inhibitory role in A. philoxeroides and estimate the usage amount of $A$. philoxeroides in order to better evaluate the ecological safety of its application as an algicide.

Polysaccharides (PSs) are a kind of macromolecular substances with high activity. It has been reported that various biological factors (predation, competition) and nonbiological factors (nutrition, temperature, light) can affect the production and release of PSs from M. aeruginosa (Zhu et al., 2014). The presence of PSs can not only promote algal cells to form large coenobium so as to protect cells from invasion, but also had the ability to remove excess ROS in cells to relieve oxidative stress reaction (EI-Sheekh et al., 2012). It was found in our study that both intracellular polysaccharides (IPSs) and extracellular polysaccharides (EPSs) contents increased with the increasing concentration of extracts from different plant parts of A. philoxeroides after $72 \mathrm{~h}$ (Fig. 4). And the change of the PSs was consistent with that of MCs contents, indicating that algal cells could produce MCs and PSs, and improve the yield with the increase of stress intensity for self-protection in the face of awful environment. Both MCs and PSs may be regulated by cell peroxidation caused by oxygen radicals, and a certain amount of MCs could activate PSs synthesis genes (Mohamed, 2008). For the reason why the content of EPSs was much higher than that of IPSs, some studies have mentioned that EPSs were produced by IPSs and then secreted to the outside of the cells, and there was a significant positive correlation between them, particularly, under terrible environmental conditions, cells would try to release more PSs outside (Liu et al., 2020).

\section{Conclusions}

Our current study revealed that the root, stem and leaf extracts of $A$. philoxeroides could inhibit the growth of $M$. aeruginosa. It was also found that root extract had the strongest inhibitory effect, followed by stem and leaf, which may be related to the specific allelochemicals contained in different plant parts of A. philoxeroides. With the extension of culture time and the increase of extracts concentration, the superfluous generation of $\mathrm{O}_{2}^{-}$led to cell damage and the contents of MDA and nucleic acid increased. At the same time, M. aeruginosa cells could resist harmful irritation by releasing microcystins and polysaccharides in a dependent manner with the concentration of the extracts.

Nonetheless, the contents discussed in this study are still insufficient. The important allelochemicals in the extracts of $A$. philoxeroides and more internal mechanisms limiting the growth of $M$. aeruginosa will be the focus of future research. Meanwhile, measuring the pros and cons of ecological application of plant aqueous extracts remains the key, and a large number of studies under natural conditions are requisite. 
Acknowledgement. We thank the Natural Science Foundation of Anhui Province (No. KJ2019A0507), the Provincial Key Laboratory of Biotic Environment and Ecological Safety in Anhui, the Foundation of the Anhui Provincial Key Laboratory of the Conservation and Exploitation of Biological Resources for financial support.

\section{REFERENCES}

[1] Apel, K., Hirt, H. (2004): Reactive oxygen species: metabolism, oxidative stress and signal transduction. - Annual Review of Plant Biology 55: 373-399.

[2] Carmichael, W. W., Boyer, G. L. (2016): Health impacts from cyanobacteria harmful algae blooms: implications for the North American Great Lakes. - Harmful Algae 54: 194-212.

[3] Chen, L., Mao, F. J., Kirumba, G. C., Jiang, C., Manefield, M., He, Y. L. (2015): Changes in metabolites, antioxidant system, and gene expression in Microcystis aeruginosa under sodium chloride stress. - Ecotoxicology and Environmental Safety 122: 126-135.

[4] Chen, L. F., Wang, Y., Shi, L. L., Zhao, J. C., Wang, W. H. (2019): Identification of allelochemicals from pomegranate peel and their effects on Microcystis aeruginosa growth. - Environmental Science and Pollution Research 26(22): 22389-22399.

[5] Davey, M. W., Stals, E., Panis, B., Keulemans, J., Swennen, R. L. (2005): Highthroughput determination of malondialdehyde in plant tissues. - Analytical Biochemistry 347(2): 201-207.

[6] EI-Sheekh, M. M., Khairy, H. M., EI-Shenody, R. (2012): Algal production of extra and intra-cellular polysaccharides as an adaptive response to the toxin crude extract of Microcystis aeruginosa. - Iranian Journal of Environmental Health Science \& Engineering 9(1): 10.

[7] García, A. C., Santos, L. A., de Souza, L. G. A., Tavares, O. C. H., Zonta, E., Gomes, E. T. M., García-Mina, J. M., Berbara, R. L. L. (2016): Vermicompost humic acids modulate the accumulation and metabolism of ROS in rice plants. - Journal of Plant Physiology 192: 56-63.

[8] Greenfield, D. I., Duquette, A., Goodson, A., Keppler, C. J., Williams, S. H., Brock, L. M., Stackley, K. D., White, D., Wilde, S. B. (2014): The effects of three chemical algaecides on cell numbers and toxin content of the cyanobacteria Microcystis aeruginosa and Anabaenopsis sp. - Environmental Management 54(5): 1110-1120.

[9] Han, S. I., Kim, S., Choi, K. Y., Lee, C., Park, Y., Choi, Y. E. (2019): Control of a toxic cyanobacterial bloom species, Microcystis aeruginosa, using the peptide HPA3NT3-A2. - Environmental Science and Pollution Research 26: 32255-32265.

[10] Herrera, N., Florez, M. T., Velasquez, J. P., Echeverri, F. (2019): Effect of Phenyl-Acyl compounds on the growth, morphology, and toxin production of Microcystis aeruginosa Kützing. - Water 11(2): 236.

[11] Hou, X. Y., Huang, J., Tang, J. H., Wang, N., Zhang, L., Lei, G., Sun, Y. F., Yang, Z., Huang, Y. (2019): Allelopathic inhibition of juglone (5-hydroxy-1,4-naphthoquinone) on the growth and physiological performance in Microcystis aeruginosa. - Journal of Environmental Management 232: 382-386.

[12] Huang, Y. Y., Bai, Y., Wang, Y., Kong, H. N. (2013): Allelopathic effects of the extracts from an invasive species Solidago canadensis L. on Microcystis aeruginosa. - Letters in Applied Microbiology 57(5): 451-458.

[13] Huang, Y. J., Ge, Y. Y., Wang, Q. L., Zhou, H., Liu, W. X., Christie, P. (2017): Allelopathic effects of aqueous extracts of Alternanthera philoxeroides on the growth of Zoysia matrella. - Polish Journal of Environmental Studies 26(1): 97-105.

[14] Kaur, S., Srivastava, A., Kumar, S., Srivastava, V., Ahluwalia, A. S., Mishra, Y. (2019): Biochemical and proteomic analysis reveals oxidative stress tolerance strategies of 
Scenedesmus abundans against allelochemicals released by Microcystis aeruginosa. Algal Research 41: 101525.

[15] Lapointe, B. E., Herren, L. W., Debortoli, D. D., Vogel, M. A. (2015): Evidence of sewage-driven eutrophication and harmful algal blooms in Florida's Indian River Lagoon. - Harmful Algae 43: 82-102.

[16] Li, J., Liu, Y. G., Zhang, P. Y., Zeng, G. M., Cai, X. X., Liu, S. B., Yin, Y. C., Hu, X. J., $\mathrm{Hu}, \mathrm{X}$., Tan, X. F. (2016): Growth inhibition and oxidative damage of Microcystis aeruginosa induced by crude extract of Sagittaria trifolia tubers. - Journal of Environmental Sciences 43: 40-47.

[17] Liu, S. Y., Tan, Y., Ma, F., Fu, H. Z., Zhang, Y. (2020): Effects of electron beam irradiation on proteins and exopolysaccharide production and changes in Microcystis aeruginosa. - International Journal of Radiation Biology 96: 689-696.

[18] Masoodi, A., Sengupta, A., Khan, F. A., Sharma, G. P. (2013): Predicting the spread of alligator weed (Alternanthera philoxeroides) in Wular lake, India: a mathematical approach. - Ecological Modelling 263: 119-125.

[19] Mecina, G. F., Dokkedal, A. L., Saldanha, L. L., Chia, M. A., Cordeiro-Araújo, M. K., do Carmo Bittencourt-Oliveira, M., da Silva, R. M. G. (2017): Response of Microcystis aeruginosa BCCUSP 232 to barley (Hordeum vulgare L.) straw degradation extract and fractions. - Science of The Total Environment 599-600: 1837-1847.

[20] Mecina, G. F., Chia, M. A., Cordeiro-Araújo, M. K., do Carmo Bittencourt-Oliveira, M., Varela, R. M., Torres, A., Molinillo, J. M. G., Macías, F. A., da Silva, R. M. G. (2019): Effect of flavonoids isolated from Tridax procumbens on the growth and toxin production of Microcystis aeruginosa. - Aquatic Toxicology 211: 81-91.

[21] Mohamed, Z. A. (2008): Polysaccharides as a protective response against microcystininduced oxidative stress in Chlorella vulgaris and Scenedesmus quadricauda and their possible significance in the aquatic ecosystem. - Ecotoxicology 17(6): 504-516.

[22] Ni, L. X., Jie, X. T., Wang, P. F., Li, S. Y., Wang, G. X., Li, Y. P., Li, Y., Acharya, K. (2015): Effect of linoleic acid sustained-release microspheres on Microcystis aeruginosa antioxidant enzymes activity and microcystins production and release. - Chemosphere 121: 110-116.

[23] Pal, M., Yesankar, P. J., Dwivedi, A., Qureshi, A. (2020): Biotic control of harmful algal blooms (HABs): A brief review. - Journal of Environmental Management 268: 110687.

[24] Pereira, A. S., Dorneles, A. O. S., Bernardy, K., Sasso, V. M., Bernardy, D., Possebom, G., Rossato, L. V., Dressler, V. L., Tabaldi, L. A. (2018): Selenium and silicon reduce cadmium uptake and mitigate cadmium toxicity in Pfaffia glomerata (Spreng.) Pedersen plants by activation antioxidant enzyme system. - Environmental Science and Pollution Research 25(19): 18548-18558.

[25] Portela, R., Vicente, J. R., Roiloa, S. R., Cabral, J. A. (2020): A dynamic model-based framework to test the effectiveness of biocontrol targeting a new plant invader-the case of Alternanthera philoxeroides in the Iberian Peninsula. - Journal of Environmental Management 264: 110349.

[26] Prabakaran, K., Li, J., Anandkumar, A., Leng, Z., Zou, C. B., Du, D. (2019): Managing environmental contamination through phytoremediation by invasive plants: a review. Ecological Engineering 138: 28-37.

[27] Rzymski, P., Klimaszyk, P., Jurczak, T., Poniedzialek, B. (2020): Oxidative stress, programmed cell death and microcystin release in Microcystis aeruginosa in response to Daphnia grazers. - Frontiers in Microbiology 11: 1201.

[28] Shi, Y., Cai, M., Zhou, L., Wang, H. (2018): The structure and function of cell membranes studied by atomic force microscopy. - Seminars in Cell \& Developmental Biology 73: 31-44.

[29] Sun, X. X., Choi, J. K., Kim, E. K. (2004): A preliminary study on the mechanism of harmful algal bloom mitigation by use of sophorolipid treatment. - Journal of Experimental Marine Biology and Ecology 304(1): 35-49. 
[30] Suzuki, Y., Johuchi, T., Saijo, H., Takahashi, K., Ashitani, T. (2020): Inhibition of the harmful alga Microcystis aeruginosa by sugi (Cryptomeria japonica) bark. - Journal of Wood Science 66(1): 75.

[31] Tazart, Z., Douma, M., Tebaa, L., Loudiki, M. (2019): Use of macrophytes allelopathy in the biocontrol of harmful Microcystis aeruginosa blooms. - Water Science \& Technology Water Supply 19(1): 245-253.

[32] Tsai, K. P. (2015): Effects of two copper compounds on Microcystis aeruginosa cell density, membrane integrity, and microcystin release. - Ecotoxicology and Environmental Safety 120: 428-435.

[33] Uddin, M. N., Robinson, R. W., Buultjens, A., AI Harun, M. A. Y., Shampa, S. H. (2017): Role of allelopathy of Phragmites australis in its invasion processes. - Journal of Experimental Marine Biology and Ecology 486: 237-244.

[34] Wu, X., Wu, H., Chen, J. R., Ye, J. Y. (2013): Effects of allelochemical extracted from water lettuce (Pistia stratiotes Linn.) on the growth, microcystin production and release of Microcystis aeruginosa. - Environmental Science and Pollution Research 20(11): 8192-8201.

[35] Yuan, R. Y., Li, Y., Li, J. H., Ji, S. H., Wang, S., Kong, F. L. (2020): The allelopathic effects of aqueous extracts from Spartina alterniflora on controlling the Microcystis aeruginosa blooms. - Science of The Total Environment 712: 136332.

[36] Zhang, S. H., Benoit, G. (2019): Comparative physiological tolerance of unicellular and colonial Microcystis aeruginosa to extract from Acorus calamus rhizome. - Aquatic Toxicology 215: 105271.

[37] Zhang, T. T., Zheng, C. Y., Hu, W., Xu, W. W., Wang, H. F. (2010): The allelopathy and allelopathic mechanism of phenolic acids on toxic Microcystis aeruginosa. - Journal of Applied Phycology 22: 71-77.

[38] Zhao, W., Zheng, Z., Zhang, J. L., Roger, S. F., Luo, X. Z. (2019): Allelopathically inhibitory effects of eucalyptus extracts on the growth of Microcystis aeruginosa. Chemosphere 225: 424-433.

[39] Zhu, W., Dai, X. X., Li, M. (2014): Relationship between extracellular polysaccharide (EPS) content and colony size of Microcystis is colonial morphology dependent. Biochemical Systematics and Ecology 55: 346-350. 